\title{
Let the children go - advocacy for children in detention by the Royal Australasian College of Physicians
}

\section{Regardless of other considerations, the health perspective requires that the detention of asylum seeker children must stop now}

$\mathbf{N}$ elson Mandela's words, "there can be no keener revelation of a society's soul than the way in which it treats its children", should give Australian immigration policymakers pause. ${ }^{1}$ The evidence is in, and it's irrefutable - Australia's detention of asylum seekers is harmful to both adults and children, and children are often scarred for life by their experiences. ${ }^{2,3}$ Detained children experience significant language and developmental delays, sleep and behaviour disorders, mental health conditions (such as post-traumatic stress disorder, depression, anxiety, self-harm and suicidality), and inadequately treated physical health conditions at greater rates than refugee children who are not detained..$^{2-4}$ The recent Australian Human Rights Commission report, The forgotten children, found that $85 \%$ of parents and children reported negative effects on their mental health while in detention. In the same report, clinician-rated assessments of children found 34\% had mental health problems that would warrant referral to hospital-based outpatient mental health services for treatment, compared with $2 \%$ of children in the general Australian community. ${ }^{4}$ Exposure to parental depression, helplessness and uncertainty, compounded by family separation and incarceration in harsh and unstimulating environments, are all contributory factors.

\section{"There are no circumstances, from a health perspective, in which conditions in detention are acceptable"}

The Royal Australasian College of Physicians (RACP) has been publicly opposed to the detention of children for more than 12 years. Over the terms of successive governments from both sides of politics, the RACP has consistently advocated, both in the media and directly to decisionmakers, the release of all children and their families from immigration detention, and recommended legislative change to end immigration detention once and for all. In May, the RACP released a comprehensive position statement on refugee and asylum seeker health. Physicians from across our specialties have reviewed the facts, both through firsthand visits to detention centres and by close analysis of the health data. Our position is this: it is imperative that detention of asylum seekers for any length of time must be stopped. There are no circumstances, from a health perspective, in which conditions in detention are acceptable.

Public opinion supports the current approach to immigration policy, with a recent poll indicating that $34 \%$ of the community considers the government is taking "the right approach", while $27 \%$ believes it is "too soft". ${ }^{5}$ But health professionals have a responsibility to hold policymakers to account. We suggest public views are fed by fear and systematic exposure to misinformation about "illegals" and "queue jumpers". If we were genuinely interested in preventing drowning, we would work with our neighbours to develop a regional solution that focused on causes, not just deterrence. ${ }^{6}$

\section{Our legal commitments - and our moral responsibilities}

Australia is the only country where mandatory detention is enshrined in legislation. In 2013, the United Nations Human Rights Committee concluded that the arbitrary and protracted nature of detention by Australia, combined with the difficult conditions of detention, were "cumulatively inflicting serious, irreversible psychological harm" upon detainees. Australia was found to be in breach of Article 7 (prohibition of cruel, inhuman or degrading treatment) and Article 10 (requirement that persons deprived of their liberty be treated with humanity and respect for their inherent dignity) of the International Covenant on Civil and Political Rights. ${ }^{7}$ The RACP was therefore deeply disappointed with the government's response to The forgotten children report; RACP Fellows had helped to prepare this sobering account of the ongoing harms of detention. The appropriate response would have been immediate action to release all children. ${ }^{4}$

There has been welcome progress, such as the closure of the remote detention facilities on Christmas Island and the widespread release of children and families over the past 6 months, albeit on temporary or bridging visas. Notably, these visas do not relieve the fear of being returned to lifethreatening circumstances, and have been shown to have their own negative mental health impact. ${ }^{8}$ Despite the progress, 1848 people, including 124 children, remained detained in onshore facilities as of 31 March 2015, and 1707 people were detained offshore, including 103 children on Nauru. On average, people still spend 394 days in detention. ${ }^{9}$ The current asylum seeker system costs Australian taxpayers more than 3 billion dollars annually. ${ }^{10}$

Mahatma Ghandi said, "In a gentle way you can shake the world". We encourage doctors to write to their local members of parliament, and make their views known in as many forums as possible. Asylum seeker health is not about politics, but about our humanity. We are optimistic

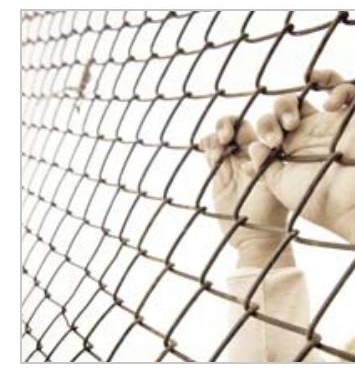

Nicholas J Talley MD, PhD, FRACP

Karen J Zwi FRACP, MRCP, MSc 2,3

1 University of Newcastle, Newcastle, NSW. 2 University of New South Wales, Sydney, NSW. 3 Sydney Children's Hospital, Sydney, NSW.

Nicholas.Talley@ newcastle.edu.au

doi: 10.5694/mjal5.00515 
that, with continued focus on the negative health impacts of this policy, public opinion will eventually turn, and detaining children who are seeking asylum in our country will become a policy of the past.

1 Mandela N. Speech by President Nelson Mandela at the launch of the Nelson Mandela Children's Fund, 8 May 1995. http:// $\mathrm{db}$.nelsonmandela.org/speeches/pub_view.asp?ItemID=NMS2 50\&txtstr=Mahlamba\&pg=item (accessed May 2015).

2 Robjant K, Hassan R, Katona C. Mental health implications of detaining asylum seekers: systematic review. $\mathrm{Br} J$ Psychiatry 2009; 194: 306-312.

3 Dudley M, Steel Z, Mares S, Newman L. Children and young people in immigration detention. Curr Opin Psychiatry 2012; 25: 285-292.

4 Australian Human Rights Commission. The Forgotten Children: national inquiry into children in immigration detention 2014. Sydney: AHRC, 2014. https://www.humanrights.gov.au/sites/ default/files/document/publication/forgotten_children_2014. pdf (accessed May 2015).

5 Essential Research. The Essential Report, 14 April 2015. http:// essentialvision.com.au/documents/essential_report_150414. pdf (accessed April 2015).

6 Burnside J. Asylum seekers can be managed with cheaper and more humane options. The Age (Melbourne) 2014; 19 June.
Competing interests: Nicholas Talley is President of the Royal Australasian College of Physicians (RACP), and Karen Zwi is Chair of the RACP Working Party on Refugee and Asylum Seeker Health.

Provenance: Commissioned; not externally peer reviewed.

References are available online at www.mja.com.au.

http://www.theage.com.au/comment/asylum-seekers-canbe-managed-with-cheaper-and-more-humane-options20140618-zscza.html_(accessed May 2015).

7 McAdam J. UN slams Australia's treatment of refugees. The Lowy Interpreter 2013; 27 Aug. http://www.lowyinterpreter. org/post/2013/08/27/UN-Human-Rights-Committee-slamsAustralias-treatment-of-refugees.aspx?COLLCC $=902060374 \&$ (accessed May 2015).

8 Steel Z, Silove D, Brooks R, et al. Impact of immigration detention and temporary protection on the mental health of refugees. Br J Psychiatry 2006; 188: 58-64.

9 Department of Immigration and Border Protection (Australia). Immigration detention and community statistics summary, 31 March 2015. http://www.immi.gov.au/About/Documents/ detention/immigration-detention-statistics-mar2015.pdf (accessed Mar 2015).

10 National Commission of Audit (Australia). Towards responsible government. The report of the National Commission of Audit. Phase one. Feb 2014. http://www.ncoa.gov.au/report/docs/ phase_one_report.pdf (accessed May 2015). 